\title{
Motivational and Semantic Profiles in Patients with Diabetes Mellitus
}

\section{Мотиваційно-смислові профілі хворих на цукровий діабет}

\section{Liudmyla Krupelnytska}

Dr. in Psychology, Professor, Taras Shevchenko National University of Kyiv, Kyiv (Ukraine)

ORCID ID: https://orcid.org/0000-0002-0594-2369

Researcher ID: http://www.researcherid.com/rid/S-8523-2019

SCOPUS ID: 57210893985

E-mail: krlyuda@gmail.com

\section{Людмила Крупельницька}

Доктор психологічних наук, професор, Київський національний університет імені Тараса Шевченка, м. Киӥв (Україна)

\section{Iryna Burovska}

Postgraduate Student of Faculty of Psychology, Taras Shevchenko National University of Kyiv, Kyiv (Ukraine)

ORCID ID: https://orcid.org/0000-0002-4156-7658

E-mail: iryna.burovska@gmail.com

\section{Ірина Буровська}

Аспірантка факультету психології, Київський національний університет імені Тараса Шевченка, м. Київ (Україна)

The contribution of the author: Krupelnytska L. $-50 \%$, Burovska I. $-50 \%$. Авторський внесок: Крупельницька Л. - 50\%, Буровська І. - 50 \%.

Address for correspondence, e-mail: kpnu_lab_ps@ukr.net Copyright: (C) Krupelnytska Liudmyla, Burovska Iryna

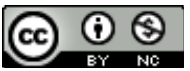
The article is licensed under CC BY-NC 4.0 International (https://creativecommons.org/licenses/by-nc/4.0/)

(C) Krupelnytska Liudmyla, Burovska Iryna

DOI (article): https://doi.org/10.32626/2227-6246.2021-52.106-135 


\section{ABSTRACT}

The introduction shows the relevance of the problem of studying the features of the motivational and semantic sphere of patients with diabetes mellitus; this area plays a leading role in the formation of both "healthy» and "painful» patients' attitudes.

The aim of the article is to establish, analyze and describe the motivational and semantic profiles of patients with diabetes mellitus.

In our research the following methods were used: theoretical analysis and generalization of the provisions contained in the psychological and medical literature on the research topic; psychodiagnostic methods, such as test "Meaningful life orientations» (Leontiev, 2000), the test "Diagnosis of the motivational structure of personality» (Milman, 1990). Methods of mathematical statistics were also used to analyze the obtained data.

The results of the research. The study involved 79 people who were treated at the Kyiv City Endocrinology Center (among them: men - 31, women - 48, average age - 52.22, $\sigma-16.61$. Twenty-five people were diagnosed with type 1 diabetes mellitus and 54 - with type 2 diabetes mellitus.

It is established that the generalized motivational and semantic profile of patients with diabetes mellitus reflects the average level of meaningfulness of life, reduced level of life goals, satisfactory interest in life and satisfaction with self-realization. Low locus of control "Me» is combined with a sufficient indicator of locus of control "Life»; consequently, the respondents believe in the fundamental possibility of managing life, but they do not believe in their own ability to control it. The participants are characterized by a predominance of motives for survival in conditions of illness, the tendency to abandon creative self-realization, and participation in public life.

With the help of cluster analysis 5 clusters were identified and analyzed. It contains specific profiles of patients with diabetes mellitus: "Typical»; "Meaningful»; "Contradictory isolationists»; "Concerned with self-preservation» and "Meaningless».

The analysis made it possible to make conclusions about the content and level of motivational and semantic parameters of patients with diabetes in general; as well as, include people in individual clusters. Prospects for further research include the search for links between motivational and semantic profiles with personal factors, identifying factors that affect the nature of the organization of motivational and semantic structure in patients with diabetes.

(C) Krupelnytska Liudmyla, Burovska Iryna DOI (article): https://doi.org/10.32626/2227-6246.2021-52.106-135 
DOI: https://doi.org/10.32626/2227-6246.2021-52

2021. випУСК 52

Key words: patients with diabetes mellitus, motivational-semantic profiles, cluster analysis, clusters, motives, meanings, meaningful life orientations.

\section{Introduction}

In Ukraine, as well as around the world, there is a constant increase in the incidence of diabetes mellitus. The Center for Public Health of the Ministry of Health (Site of Ministry of Health of Ukraine, 2016) notes that the prevalence of diabetes mellitus in Ukraine has increased by half over the past 10 years. Almost $3 \%$ of primary disability of the adult population in Ukraine is a consequence of diabetes mellitus. Studies of medical aspects in domestic and foreign publications are widely represented. There aren't numerous psychological researches that cover all-important psychological aspects of this disease. Such topical aspects should include motivational and semantic features of patients with diabetes mellitus and the possibility of influencing it. After all, the motivational and semantic sphere of personality plays a leading role in the formation of both «healthy» and "painful» attitudes (Leontiev, 2007: 152-159), that further contribute to the maintenance of a patient's healthy or unhealthy lifestyle. In this research topic, we find a few domestic and foreign publications.

They are devoted to the motivational component of the patient's internal picture of the disease with a vital threat in somatic diseases (Shtrakhova \& Arslanbekova, 2011); teenagers' locus of health control with diabetes mellitus (Kyrylova, 2017); patient's semantic aspects of physical experience with diabetes mellitus (Vasilenko, Mangushev \& Selin); features of the internal picture of the disease of people with diabetes at different stages of the disease; in particular, the motivational level of the internal picture of the disease (Kachan \& Kulak, 2015), comparison of meaningful life orientations models in patients with diabetes mellitus (García-Alandete, Marco \& Pérez, 2017).

(C) Krupelnytska Liudmyla, Burovska Iryna

DOI (article): https://doi.org/10.32626/2227-6246.2021-52.106-135 
DOI: https://doi.org/10.32626/2227-6246.2021-52

2021. випуск 52

In the works that have been written in recent years and belong to Ukrainian authors, the personal traits of patients with diabetes are correlated with the level of risk of increasing the disease and the peculiarities of response to the disease depending on its severity (Tkachenko, 2017a; Tkachenko, 2017b). Moreover, a lot of attention was dedicated to negative psychological factors for the development of psychosomatic diseases (Voloshko, 2015), in the researches the phenomenology and practical aspects of psychological health were analyzed (Shtyfurak \& Shportun, 2019), the possibilities of psychological correction of emotional disorders in somatogenic and phenomenology aspects were studied (Maksimenko, 2015; Maksymenko, 2016); additionally, there were studied mechanisms of formation and principles of social rehabilitation of people with disabilities due to somatic diseases (Moroz, 2010), principles of training for specialists in treatment patients with somatic and mental disorders (Mykhailov, Romanova, Andrukh, Sarvir, Havrylenko, Andruh \& Aliieva, 2011).

The attention is also paid to the possibilities of spiritual growth and the coherence of spiritual aspects with the quality of life of patients with diabetes mellitus (Panahi, Ahmadi, Amjadian, Khasi, Noori, Ghajari \& Ghaderi, 2019; Heidarzadeh \& Amohammadi, 2017), age peculiarities of patients with diabetes mellitus (Kyrylova, 2017; Popova, 2019; Rudenko, Havrylenko \& Osadcha, 2016; Hajihasani \& Naderi, 2020), opportunities for growth of personal resilience (Joyce, Shand, Tighe, Laurent, Bryant \& Harvey, 2018), role of which in somatic disease is exacerbated.

However, the motivational and semantic features of this category of people and possible variants of their motivational and semantic profiles remain insufficiently covered.

The purpose of the article is to identify, analyze and describe the motivational and semantic profiles of patients with diabetes mellitus.

(C) Krupelnytska Liudmyla, Burovska Iryna DOI (article): https://doi.org/10.32626/2227-6246.2021-52.106-135 


\section{The tasks of the article}

1) To establish the motivational and semantic features of patients with diabetes mellitus.

2) To identify, analyze and describe different motivational and semantic profiles of patients with diabetes mellitus.

\section{Methods and methodology}

Analysis and generalization of the provisions contained in the psychological and medical literature on the research topic; psycho-diagnostic methods: Test «Meaningful Life Orientations» (MLO), which is an adaptation of the test J. Crambo and L. Maholyk Purpose-in-Life Test (Leontiev, 2000), test «Diagnosis of the motivational structure of personality» (Milman, 1990) are used in this research. Methods of mathematical statistics were also used to analyze the obtained data.

\section{Results and discussions}

In order to study the features of the motivational and semantic sphere of patients with diabetes mellitus and to establish options for the configuration of its components, we examined 79 people who were treated at the Kyiv City Endocrinology Center with the help of psychodiagnostics tools; among them: men -31 , women -48 , average age -52.22 , $\sigma-16.61$. Twenty-five people were diagnosed with type 1 diabetes mellitus and 54 - with type 2 diabetes mellitus.

We obtained indicators measured by tests of MLO and Diagnosis of motivational structure of personality. However, the obtained data needed further systematization. As the most suitable procedure for data classification, we used cluster analysis, because we did not have previous hypotheses about possible classes of data.

We chose the hierarchical cluster analysis, as the number of analyzed observations was relatively small (79 people). Considering the type of variables and the scale to which they (C) Krupelnytska Liudmyla, Burovska Iryna

DOI (article): https://doi.org/10.32626/2227-6246.2021-52.106-135 
belong, we chose the Ward method. During the clustering, 5 clusters were obtained. The decision on their number was made on the basis of the analysis of the table of the order of agglomeration, obtained using the program of statistical analysis SPSS 26, and the derived tree diagram.

The analysis of the distribution of observations by clusters is shown on the indicators of the average measured variables (Tab. 1).

Table 1

Distribution of observations by clusters

\begin{tabular}{|c|c|c|c|c|}
\hline \multirow{2}{*}{ № of cluster } & \multicolumn{5}{|c|}{$\begin{array}{c}\text { The number of observations depends } \\
\text { on the number of clusters }\end{array}$} \\
\cline { 2 - 5 } & At $\mathbf{5}$ & At $\mathbf{4}$ & At $\mathbf{3}$ & At 2 \\
\cline { 2 - 5 } & $\mathbf{N}$ & $\mathbf{N}$ & N & N \\
\hline 1 & 32 & 38 & 39 & 41 \\
\hline 2 & 6 & 3 & 3 & 38 \\
\hline 3 & 3 & 27 & 38 & 0 \\
\hline 4 & 27 & 11 & 0 & 0 \\
\hline 5 & 11 & 0 & 0 & 0 \\
\hline N general & 79 & 79 & 79 & 79 \\
\hline
\end{tabular}

As we can see from the Tab. 1, observations were divided into 5 clusters. In the case of a solution with a smaller number of clusters ( 3 or 4 ) in one of the clusters, as well as in the case of a solution with five clusters, there are three observations; therefore, reducing the number of clusters does not eliminate this problem. In the solution with five clusters, the first, largest cluster obtained in a four-cluster solution is divided into two smaller ones, which are fairly well interpreted. So, the optimal number of clusters is 5, which is the number we will analyze.

In Tab. 2, we can see the data on average values and standard deviations of the studied parameters.

(C) Krupelnytska Liudmyla, Burovska Iryna DOI (article): https://doi.org/10.32626/2227-6246.2021-52.106-135 
DOI: https://doi.org/10.32626/2227-6246.2021-52

2021. виПуск 52

0
0
0
$\sigma$
$\sigma$

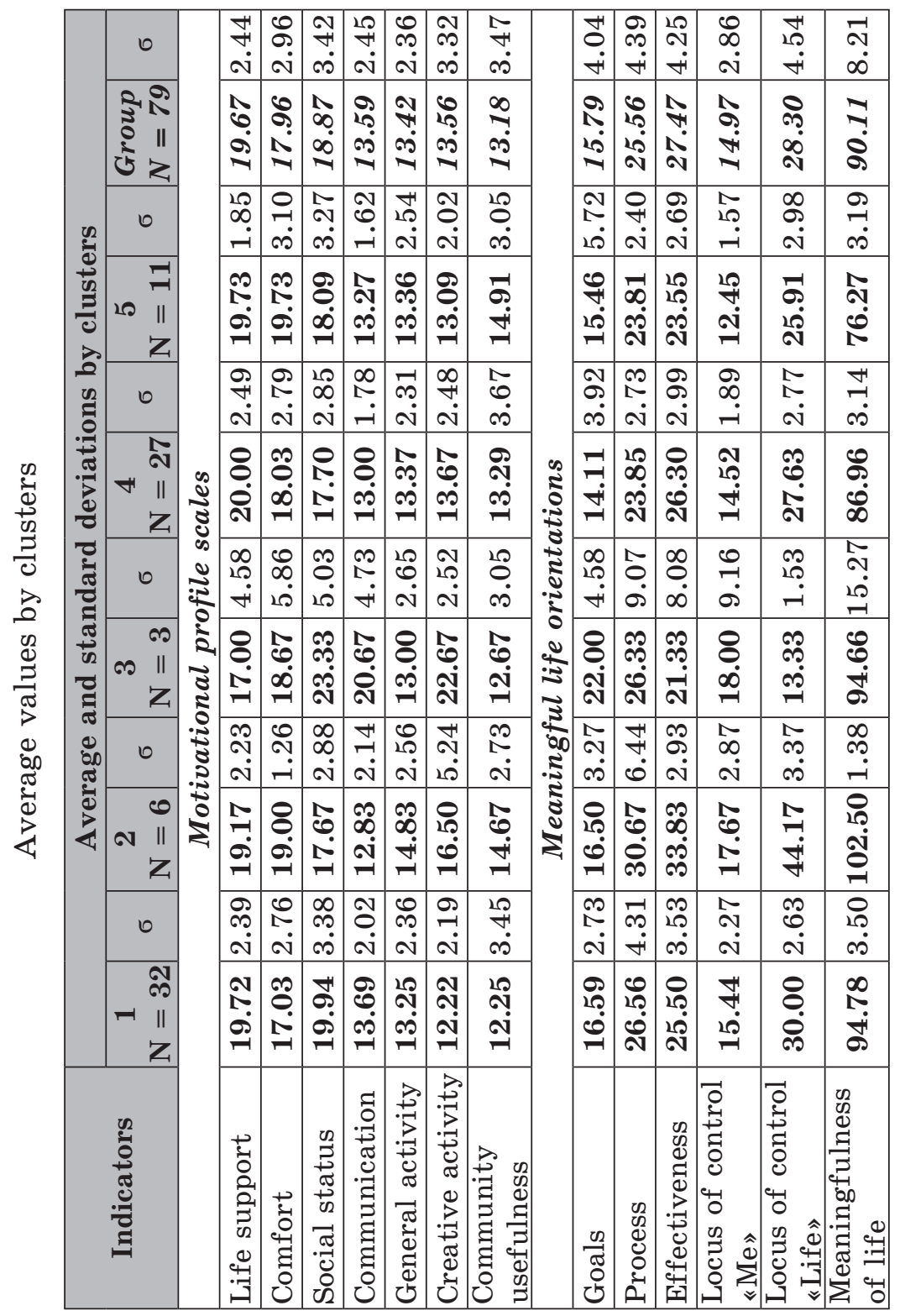

(C) Krupelnytska Liudmyla, Burovska Iryna

DOI (article): https://doi.org/10.32626/2227-6246.2021-52.106-135 
DOI: https://doi.org/10.32626/2227-6246.2021-52

2021. випУСК 52

To illustrate the data obtained, we display them graphically. Firstly, we present the motivational and semantic profile of the group in general, then motivational and semantic profiles of different clusters. Fig. 1 shows the configuration of motivational indicators in general for the group.

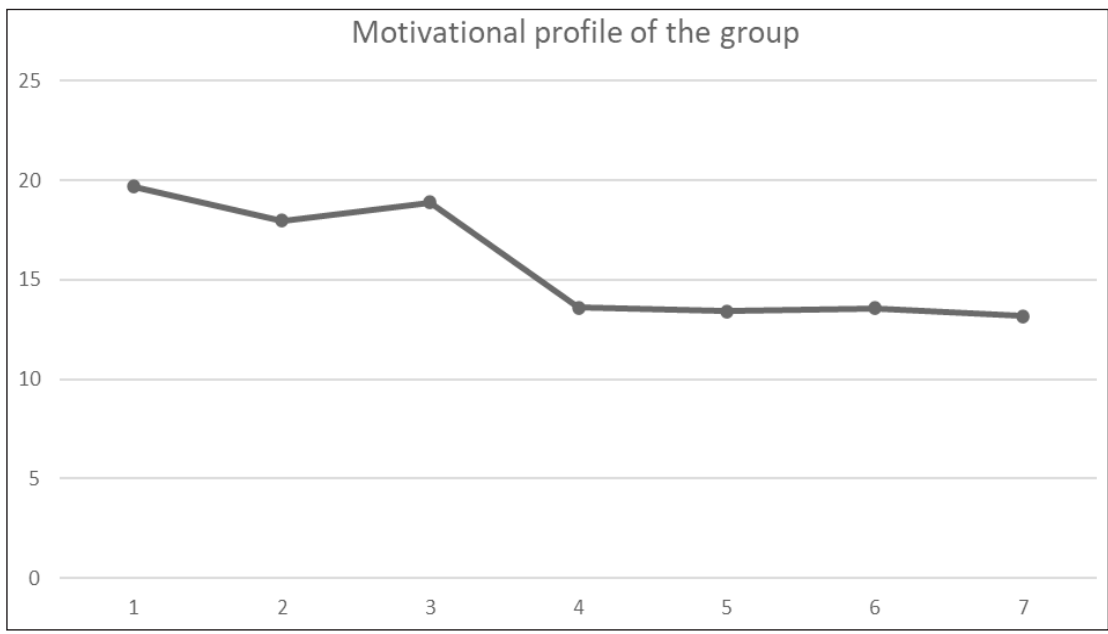

Fig. 1. Motivational profile scales by group

Note: 1 - life support; 2 - comfort; 3 - social status; 4 - communication; 5 - general activity; 6 - creative activity; 7 - community usefulness.

The motivational profile reflects the peculiarities of the motivation of this group of people. If we focus on the normative indicators (Milman, 1990), patients with diabetes mellitus generally have a high level of motives for life, comfort, and social status. At the same time, the level of motives for communication, general and creative activity, the community usefulness is reduced. This configuration of the motivational profile indicates the predominance of motives for survival in the conditions of illness, refusal of creative self-realization, and participation in public life. Obviously, the situation of life

(C) Krupelnytska Liudmyla, Burovska Iryna DOI (article): https://doi.org/10.32626/2227-6246.2021-52.106-135 
DOI: https://doi.org/10.32626/2227-6246.2021-52

2021. випуск 52

in the conditions of the disease is a situation of significant motivational adjustment.

Obtained data are in close agreement with the data available in psychological publications. In particular, the results of the study by O. Kachan and O. Kulak (Kachan \& Kulak, 2015) indicate that the motivational level of the internal picture of the disease associated with lifestyle changes; therefore, it is reflected in the characteristics of the disease, the nature of activities aimed to returning and maintaining the health. Depending on the duration of the disease, the motivational level of the internal picture of the disease is changed. If at the beginning of the disease the peculiarities of patients' motivation are associated with insufficient seriousness to the disease, then at later stages the specificity of motivation determines the serious acceptance of the fact of the disease and the necessity to change lifestyle in accordance with this fact.

We can continue the opinion of the authors and notice the probability of anosognosia of the disease at the first stage, which at the psychological level is a strengthening of psychological defense mechanisms (Oganesyan, Gubina \& Karoyan, 2015). It affects the patients' motivational sphere, determining their inability to accept the severity of the health problem consciously and an adequate assessment of the needs that arise during the disease in their daily lives. Therefore, in the structure of the motivational sphere, there are more expectations about a speedy recovery and return to a normal lifestyle, which in diabetes is an unrealistic expectation. Eventually, as the duration of the disease increases, a conscious attitude to the disease and a focus on maintaining a comfortable life as the conditions of a new reality increase as well.

According to the authors, the patients' activity can be seen in different ways, depending on the motivational characteristics and intellectual abilities, which can have both stimulating and deterrent effects. On the one hand, the intellectual ability to compare objective, external possibilities, and subjective in(c) Krupelnytska Liudmyla, Burovska Iryna

DOI (article): https://doi.org/10.32626/2227-6246.2021-52.106-135 
ternal possibilities on the other - determine the forecast of the effectiveness of maintaining health actions.

It should be noted that the high levels of motivation do not always involve active action, because motives are refracted through different personal areas: values, will, and intelligence. Therefore, the presence of a desire to act or the presence of an appropriate solution does not necessarily trigger a behavioral activity component. This observation should be taken into account, avoiding a simplistic, reductionist approach to the analysis of the real and resulting aspects of motivation of patients with diabetes.

Fig. 2 shows the configuration of meaningful life indicators in general by the group.

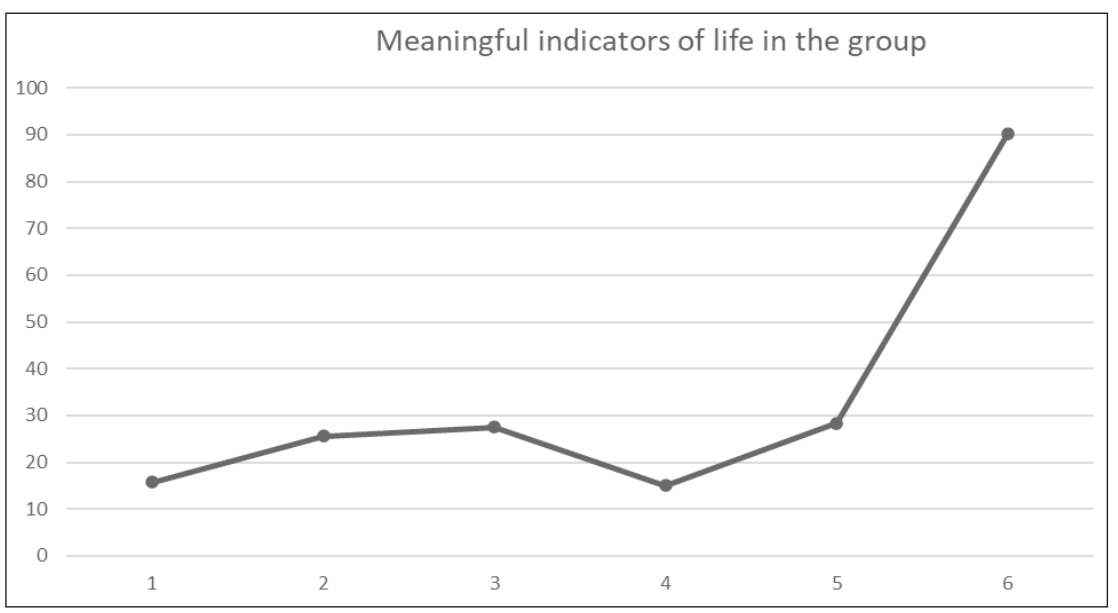

Fig. 2. Scales of semantic profile by group

Note: 1 - goals in life; 2 - the process of life; 3 - the effectiveness of life; 4 - locus of «Me» control; 5 - locus of control «Life»; 6 the general indicator of meaningfulness of life.

It is noted that there are age-related changes in the emotional and semantic aspects of functioning, which must also be taken into account (Hajihasani \& Naderi, 2020). The configu-

(C) Krupelnytska Liudmyla, Burovska Iryna DOI (article): https://doi.org/10.32626/2227-6246.2021-52.106-135 
DOI: https://doi.org/10.32626/2227-6246.2021-52

2021. випуск 52

ration of the scales of the semantic profile of patients with Mellitus diabetes in comparison with similar configurations of adults and the elderly (Popova, 2019) indicates an average level of meaningfulness of life but fixes the specificity of certain semantic indicators. In particular, the rate of life goals in the group of patients with diabetes mellitus is low. Assessments of the life process, interest, and emotional saturation of life; as well as, satisfaction with self-realization, which associated with the life stage that preceded the disease, are satisfactory. The indicators of the locus of control «Me» and the locus of control «Life» are different in level; with a low indicator of the locus of control «Me», there is a sufficient indicator of the locus of control «Life». It means that the respondents believe in the fundamental possibility of managing life, but do not believe in their own ability to control it. These data are confirmed by the authors (Koshanskaya, 2007; Oganesyan, Gubina \& Karoyan, 2015), who found a high level of an external focus of the locus control in relation to health and disease in patients with diabetes mellitus.

In this category of patients, this externality of the locus of control is associated with a constant need for help from other people: doctors, relatives, etc., and dependence on them. Consequently, it is a natural specific change in personal response, associated with the situation of the disease and adequate to this situation. On the other hand, such changes in the meaning of life profile are problematic in the personal functioning of these people.

Further, we turn to the presentation of motivational and semantic profiles by clusters. Fig. 3 shows the motivational profiles for each of the 5 clusters.

As you can see from Tab. 2 and Fig. 3, motivational profiles in different clusters are specific: according to some parameters they are similar, to others - significantly different. Before proceeding to their analysis, it is necessary to determine the extent of differences between these profiles.

(C) Krupelnytska Liudmyla, Burovska Iryna

DOI (article): https://doi.org/10.32626/2227-6246.2021-52.106-135 


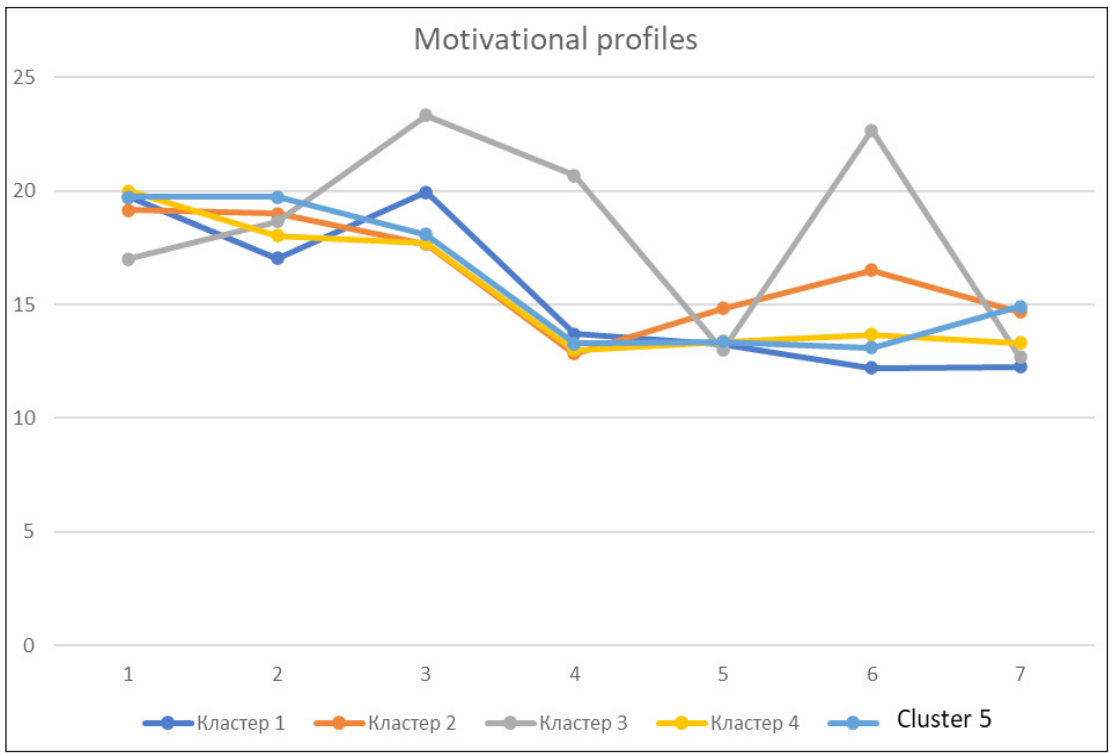

Fig. 3. Motivational profile scales for 5 clusters Note: 1 - life support; 2 - comfort; 3 - social status; 4 - communication; 5 - general activity; 6 - creative activity; 7 - community usefulness.

First of all, we present the semantic profiles of different clusters (Fig. 4), data on the differences of clusters in motivational and semantic parameters are given below.

In Fig. 4 we can see different configurations of meaningful life profiles, but so far, we cannot clearly talk about the extent of their differences. Cluster analysis shows the degree of proximity of observations within the cluster. However, it is also necessary to understand the degree of differences between the parameters by which the clusters are formed. For this purpose, we used the criteria of Kruskal-Wallis (for comparison of clusters in general) and Mann-Whitney for the pairwise comparison of clusters (Tab. 3). 


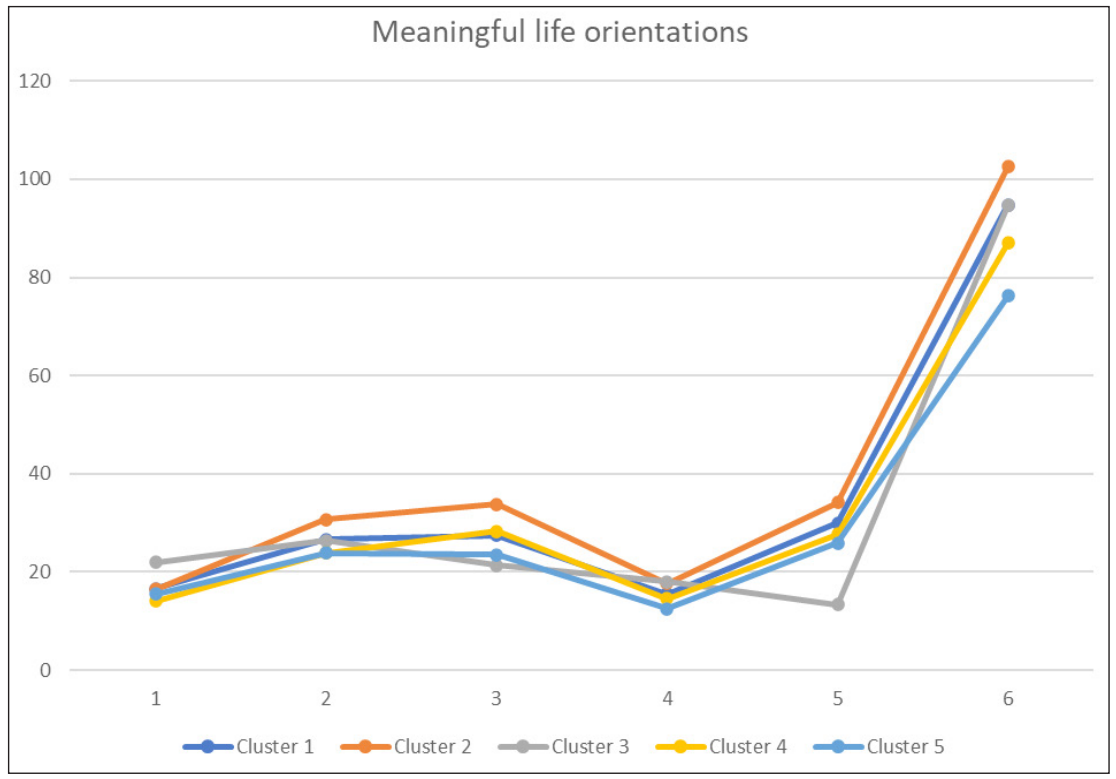

Fig. 4. Semantic profile scales for 5 clusters

Note: 1 - goals in life; 2 - the process of life; 3 - the effectiveness of life; 4 - locus of control-«Me»; 5 - locus of control «Life»; 6 the general indicator of meaningfulness of life.

Differences between clusters

\begin{tabular}{|c|c|c|c|c|c|c|c|c|c|c|c|c|c|}
\hline Clusters & G & $\mathbf{P}$ & $\mathbf{E}$ & $\begin{array}{c}\text { LC } \\
\text { «Me» }\end{array}$ & $\begin{array}{c}\text { LC } \\
\text { «Life» }\end{array}$ & ML & S & C & SS & C & GA & CA & CU \\
\hline All & $* *$ & $* *$ & $* *$ & $* *$ & $* *$ & $* *$ & & & $*$ & $*$ & & $* *$ & \\
\hline 1 and 2 & & & $* *$ & $* *$ & $* *$ & $* *$ & & $*$ & & & & $*$ & \\
\hline 1 and 3 & $*$ & & & & $* *$ & & & & & $* *$ & & $* *$ & \\
\hline 1 and 4 & $* *$ & $* *$ & & & $* *$ & $* *$ & & & $* *$ & & & $*$ & \\
\hline 1 and 5 & & & $* *$ & $* *$ & $* *$ & & & $* *$ & & & & & $*$ \\
\hline 2 and 3 & & $*$ & & $*$ & & & & & $*$ & & & \\
\hline 2 and 4 & & $* *$ & $* *$ & $* *$ & $* *$ & $* *$ & & & & & & & \\
\hline 2 and 5 & & $* *$ & $* *$ & $* *$ & $* *$ & $* *$ & & & & & & & \\
\hline
\end{tabular}

(C) Krupelnytska Liudmyla, Burovska Iryna

DOI (article): https://doi.org/10.32626/2227-6246.2021-52.106-135 


\begin{tabular}{|l|c|c|c|c|c|c|c|c|c|c|c|c|c|}
\hline Clusters & $\mathbf{G}$ & $\mathbf{P}$ & $\mathbf{E}$ & $\begin{array}{c}\text { LC } \\
\text { «Me» }\end{array}$ & $\begin{array}{c}\text { LC } \\
\text { «Life» }\end{array}$ & $\mathbf{M L}$ & $\mathbf{S}$ & $\mathbf{C}$ & $\mathbf{S S}$ & $\mathbf{C}$ & $\mathbf{G A}$ & $\mathbf{C A}$ & $\mathbf{C U}$ \\
\hline 3 and 4 & $* *$ & & & & $* *$ & & & & $*$ & $* *$ & & $* *$ & \\
\hline 3 and 5 & & & & & $* *$ & $*$ & & & & $* *$ & & $* *$ & \\
\hline 4 and 5 & & & $* *$ & $* *$ & & $* *$ & & & & & & & \\
\hline
\end{tabular}

Note: 1. Only the level of significance of differences is indicated. 2. G - goals in life; $\mathrm{P}$ - process of life; $\mathrm{E}$ - effectiveness of life; $\mathrm{LC}$ «Me» - locus of control «Me»; LC «Life» - locus of control «Life»; ML - general indicator of meaningfulness of life.

3. The Motives: $\mathrm{S}$ - support; C - comfort; $\mathrm{SS}$ - social status; C communication; GA - general activity; CA - creative activity; CU - community usefulness.

According to the Kruskal-Wallis test, which allows to check the presence of differences between several scales, differences were found for all meaningful life scales and for three motivational ones. At the same time, the significance of differences is low on two motivational scales. In general, these are scales of motives for social status, communication and creative activity.

To understand better the differences in the performance of individual clusters, it is necessary to analyze the differences obtained by pairwise comparison of the obtained clusters. Taking into account the medians of indicators in each cluster (Tab. 1) and the differences between the indicators included in different clusters (Tab. 3), we recorded the semantic difference between clusters.

Cluster 1 is the biggest one and contains 32 people. We called the people who came to it «typical»; firstly, because it is the largest cluster in terms of number of people; secondly, the people who joined it are most similar in terms of motivation and meaning of life to the group in general. Furthermore, almost all meaningful life indicators (except for the life performance indicator, which is lower than in the group in general) in this cluster are slightly higher than the group average, and the level of indicators of life support and social status is

(C) Krupelnytska Liudmyla, Burovska Iryna DOI (article): https://doi.org/10.32626/2227-6246.2021-52.106-135 
DOI: https://doi.org/10.32626/2227-6246.2021-52

2021. випУСК 52

slightly higher than the group average. However, in general this cluster consists of individuals with predominant motives for survival in the conditions of illness, which largely refuse creative self-realization and participation in public life.

Cluster 2 is small and contains only 6 people. We called these people «meaningful». They have the highest indicators of the process and efficiency of life in the whole group; as well as, the locus of control «Me» (this indicator is approximately the same as the indicator in cluster 3 ) and the locus of control «Life».

Additionally, in this cluster there is the highest overall indicator of life meaningfulness in the group. The motive of community effectiveness is slightly inferior to the indicator in cluster 5, where it is the highest; motives of general and creative activity are the highest among all clusters. At the same time, the motives of social status and communication are the lowest compared to other clusters. It means that the members of this cluster lead a meaningful lifestyle, they are active both in general and in the creative aspect, without paying much attention to social status and communication. Probably, in this case we can talk about introverted creative people who, even in conditions of illness, feel like masters of their own lives.

Cluster 3 is the smallest one, includes only 3 people. We called these people «contradictory isolationists». They are characterized by the lowest locus of control «Life» in the group; however, the highest locus of control «Me» and the lowest indicators of performance in the group, but the highest rate of life goals. The general meaning of life is average. The motivational profile of these individuals is characterized by a low level of motives of community effectiveness, but the highest level of the motive of creative activity against the other clusters.

However, the overall activity is the lowest in the group. The level of motives of social status and communication is the highest among all in the group, and the motive of life support is the lowest. It means that these individuals are also moti(c) Krupelnytska Liudmyla, Burovska Iryna

DOI (article): https://doi.org/10.32626/2227-6246.2021-52.106-135 
vated by creative activity, but this activity is «isolating», it means that they prefer to stay alone with themselves, because the level of motives for general activity and community usefulness is low.

Obviously, creative activity and the presence of goals compensate for the experience of health problems. With a high probability, we can talk about a certain level of anosognosia, which along with the implementation of motivation for creative activity results in a low level of motivation life support.

Cluster 4 is the second largest and includes 27 people. We called them «concerned with self-preservation». These individuals show a rather low rate of meaningfulness of life, medium level of the effectiveness of life and the locus of control "Life» and one of the lowest compared to other clusters indicator of the locus of control «Me». The level of evaluation of effectiveness and satisfaction with the process of life in them is defined as average, and goals are the lowest in the group. Motives of communication, general and creative activity among them are not expressed; they have the lowest level of the social status motive, but the highest indicator of the motive of life support by the group. It means that these individuals are focused on themselves and their problems. Adaptation and self-preservation are important for them, but not development and creativity.

Cluster 5 is medium in size and includes 11 people. We called them «meaningless». They show the lowest indicator of meaningfulness of life by the group, low indicators of life goals, process and effectiveness of life, the lowest in the group indicator of the locus of control "Me». In this cluster, we can see low indicators of motives of creative activity and communication, indicators of motives of life support and comfort are the highest in the group. Cluster 5 is similar to cluster 4; however, as can be seen from Tab. 2 and Tab. 3, indicators of life performance, self-control locus, and meaningfulness of life are significantly lower than in cluster 4 . It means that the meaning

(C) Krupelnytska Liudmyla, Burovska Iryna DOI (article): https://doi.org/10.32626/2227-6246.2021-52.106-135 
DOI: https://doi.org/10.32626/2227-6246.2021-52

2021. ВИПУСК 52

of life of individuals in this cluster is significantly reduced and limited by the situation of the disease, which has become dominant in their lifestyle.

It should be noted that clusters 4 and 5 are formed by groups of people with a weak motivational and semantic structure. Cluster 1 has a medium-weak motivational and semantic structure, clusters 2 and 3 - with a strong one. Such features should be noted both in psycho-correctional work and in the organization of the system of therapeutic influence with these groups.

There is no task to increase the indicators for patients who have sufficient indicators of a meaningful life, focused on certain life goals, who are satisfied with the process and results of self-realization, motivated by creative activity, treat themselves as masters of their own lives. They are adapted to the conditions of the disease in a very harmonious way. The "weaknesses» of personal functioning are compensated in them by "strengths", limitations in certain areas related to the disease; additionally, it is compensated by the expansion or removal of restrictions in the field of creative self-realization and a fuller meaning in life.

These categories of people should be tasked with maintaining their motivational and semantic orientation, creating full-fledged conditions for its implementation.

On the other hand, these categories of patients may have problems of a different nature. They may not pay enough attention to their treatment, forgetting about the disease and the need to paying attention to its presence. The implementation of compensatory mechanisms can create a kind of their own world, where is comfortable, and there is no place for a serious attitude to the disease. Therefore, these categories of patients need to be constantly informed about the objective situation with their disease, to report the risks, and seek to increase adherence to treatment.

(C) Krupelnytska Liudmyla, Burovska Iryna

DOI (article): https://doi.org/10.32626/2227-6246.2021-52.106-135 
DOI: https://doi.org/10.32626/2227-6246.2021-52

2021. випуск 52

Many authors have indicated the importance of active and motivating activities to support patients' own health. In particular, A. Shtrakhova and E. Arslanbekova note that the peculiarities of motivation form determinate the patterns of compliance of patients with a vital threat (Shtrakhova \& Arslanbekova, 2011). In other words, adherence or non-adherence to treatment depends on the content, intensity, and direction of motivational and semantic tendencies of persons to whom they belong and they have to develop in accordance with the development of the adaptive potential of thinking (Manilov, 2017).

On the contrary, patients who belong to clusters of the weak motivational and semantic structure are completely focused on the problems associated with the disease, which become a kind of semantic axis around which the life of diabetics «revolves». Such a person has the survival motives in the conditions of illness, which prevail on the motives of creative self-realization and participation in public life. In psychocorrectional and rehabilitation work with these categories of people, specialists should focus on expanding the semantic perspective of patients' lives, improving its meaning, awareness of results and goals of life; as well as, discovering additional factors of interest in the process of self-realization. First of all, such factors can include creative activity, meaningful lessons, communication, etc.

Consequently, persons with a weak motivational and semantic structure have a completely different configuration of personal problems, compared to persons with a strong structure. They clearly outline the patterns of compliance. On the one hand, persons with a strong motivational and semantic structure can talk about the potential problem of a deficit in the appointment of a doctor; on the other hand, persons with a weak structure may reflect not only adherence to the prescribed treatment but also a surplus of doctor's appointments (Tkachenko, 2017b). The latter can be expressed in an indepen-

(C) Krupelnytska Liudmyla, Burovska Iryna DOI (article): https://doi.org/10.32626/2227-6246.2021-52.106-135 
DOI: https://doi.org/10.32626/2227-6246.2021-52

2021. випУСК 52

dent increase in the recommended dose of drugs and frequency of administration; as well as, in a kind of "preventive» version of the drug. It means that excessive fixation on the problems of survival in the conditions of the disease is also problematic, and can be corrected by increasing the motives of creative activity, self-realization, and expanding the semantic perspective of life.

Important to pay attention to the distribution in clusters (Tab. 4).

Table 4

Distribution in clusters by type of disease

\begin{tabular}{|c|c|c|c|c|c|c|c|c|c|c|c|c|}
\hline \multirow{2}{*}{$\begin{array}{c}\text { Type } \\
\text { MD }\end{array}$} & \multicolumn{2}{|c|}{ Cluster 1 } & \multicolumn{2}{|c|}{ Cluster 2 } & \multicolumn{2}{|c|}{ Cluster 3 } & \multicolumn{3}{|c|}{ Cluster 4 } & \multicolumn{2}{|c|}{ Cluster 5 } & \multicolumn{2}{|c|}{ All } \\
\hline MD 1 & 8 & $\%$ & N & $\%$ & N & $\%$ & N & $\%$ & N & $\%$ & N & $\%$ \\
\hline MD 2 & 24 & 44.44 & 4 & 7.41 & 3 & 5.56 & 18 & 33.33 & 5 & 9.26 & 54 & 100 \\
\hline
\end{tabular}

Note: MD 1 - diabetes mellitus type 1; MD 2 - diabetes mellitus type 2 .

As we can see, analyzing the data in Tab. 4, cluster 4 which can be referred to as a cluster with a «strong» motivational and semantic structure contains the largest percentage of people with type 1 diabetes mellitus, approximately the same percentage of these people in cluster 1 with a «medium» motivationalsemantic structure. It means that there is no reason to talk about the dependence of the nature of the motivational and semantic structure on the type of disease.

\section{Conclusions}

An empirical study of motivational and semantic parameters in a group of people with diabetes mellitus allowed us to make the following conclusions.

1. The configuration of the motivational and semantic profile of patients with diabetes mellitus reflects the average (C) Krupelnytska Liudmyla, Burovska Iryna

DOI (article): https://doi.org/10.32626/2227-6246.2021-52.106-135 
DOI: https://doi.org/10.32626/2227-6246.2021-52

2021. випуск 52

level of meaningfulness of life, low level of life goals, but a satisfactory level of assessment of interest and emotional saturation of life; as well as, satisfaction with self-realization, which associated with the pre-disease stage. Furthermore, low locus of control «Me» presents a sufficient locus of control «Life». It means that the respondents believe in the fundamental possibility of managing life, but do not believe in their own ability to control it. There is also a predominance of motives for survival in the disease, the tendency to abandon creative self-realization and participation in public life. Obviously, the situation of life in the conditions of the disease is a situation of significant motivational adjustment. The respondents have a high level of motives for life, comfort, and social status. At the same time, the level of motives for communication, general and creative activity, the community usefulness is reduced.

2. The group of patients with diabetes is heterogeneous in motivational and semantic parameters. During the study, 5 clusters were obtained which differ in content and level of motives and meaningful life orientations of the respondents: cluster 1 - typical; cluster 2 - meaningful; cluster 3 - contradictory isolationists; cluster 4 - concerned with self-preservation and cluster 5 - meaningless.

- Individuals who are included in cluster 1 are most similar in terms of motivational and semantic indicators to the group in general. This cluster consists of individuals with predominant motives for survival in the conditions of the disease, who largely refuse creative self-realization and participation in public life.

- The people who are included in cluster 2 have the highest indicators of the process and efficiency of life, the locus of control «Me» and the locus of control «Life». Members of this cluster lead a meaningful lifestyle, they are active both in general and in the creative aspect, without paying much attention to social status and communication.

(C) Krupelnytska Liudmyla, Burovska Iryna DOI (article): https://doi.org/10.32626/2227-6246.2021-52.106-135 
DOI: https://doi.org/10.32626/2227-6246.2021-52

2021. випУСК 52

- Cluster 3 is characterized by the lowest locus of control «Life» in the group; at the same time, with the highest locus of control "Me», and the lowest performance of life in the group, but with the highest rate of life goals. These individuals are also motivated by creative activity, but this activity is «isolating», because the level of motives for general activity and community usefulness is low.

- Cluster 4 is characterized by a fairly low rate of meaningfulness of life, a low rate of locus of control «Me» and the life goals. These individuals focus on themselves and their problems. For them, important is adaptation and self-preservation but not development and creativity.

- Individuals who are included in cluster 5 have lower indicators of life performance, self-control locus, and meaningfulness of life. The meaning of life of these people is significantly reduced and limited by the situation of the disease, which has become dominant in the organization of their lifestyle.

3. Clusters 4 and 5 are formed by individuals with a weak motivational and semantic structure, cluster 1 consists of people with a medium motivational and semantic structure, and clusters 2 and 3 are formed by individuals with a strong one. The nature of the motivational and semantic structure, according to the results, does not depend on the type of diabetes. The percentage of people with type 1 diabetes who entered cluster 4 with a strong motivational and semantic structure is approximately the same as the percentage of such persons in cluster 1 with a medium motivational-semantic structure.

4. The prospects for further research include the search for links between the obtained motivational and semantic profiles with the personal factors which could be identifiable in the motivational and semantic structure of patients with diabetes mellitus that possibly influence the nature of its organization.

(C) Krupelnytska Liudmyla, Burovska Iryna

DOI (article): https://doi.org/10.32626/2227-6246.2021-52.106-135 


\section{Literature}

Василенко Т. Д., Мангушев Ф. Ю., Селин А. В. Смысловые аспекты телесного опыта хронического соматического заболевания. Курский научно-практический вестник "Человек и его здоровье». 2016. № 2. C. $116-121$.

Волошко Н. І. Психосоматичні хвороби як результат впливу негативних психологічних факторів. Збірник наукових пращь «Проблели сучасної психологї̈. 2015. № 30. С. 126-135.

Качан Е. П., Кулак А. И. Особенности внутренней картины болезни у пациентов с сахарным диабетом 2-го типа в зависимости от длительности заболевания. Журнал Белорусского государственного университета. Философия. Психология. 2015. № 1. С. 108-114.

Кирилова О. О. Новий підхід до вивчення локусу контролю здоров'я в підлітків із цукровим діабетом I типу. Український журнал дитячої ендокринологї̈. 2017. № 1. С. 16-20.

Кошанская А. Г. Взаимосвязи психологических и клинических характеристик у больных сахарным диабетом II типа при различных вариантах его течения: дис. ... канд. психол. наук: 19.00.04. Санкт-Петербург, 2007. 161 с.

Леонтьев Д. А. Психология смысла: природа, строение и динамика смысловой реальности. 3-е изд., доп. Москва : Смысл, 2007. 511 с.

Леонтьев Д. А. Тест смысложизненных ориентаций (СЖО). 2-е изд. Москва : Смысл, 2000. 18 с.

Максименко К. С. Личностно-ориентированная терапия эмоциональных расстройств при соматогениях: монография. Киев : Издательский дом «Слово», 2015. 352 с.

Максименко К. С. Особистісно-орієнтована психотерапія емоційних розладів при соматогеніях у практиці сучасної медичної психології: дис. ... д-ра психол. наук: 19.00.04. Харків, 2016. 414 с.

Манілов І. Ф. Про концептуальні положення мультимодальної сугестивної психотерапії. Збірник наукових праць «Проблели сучасної психологї̈». 2017. № 36. С. 197-207.

Мильман В. Э. Метод изучения мотивационной сферы личности. Практикум по психодиагностике. Психодиагностика мотивации и саморегуляиии. Москва : Изд-во МГУ, 1990. С. 23-43.

Михайлов Б. В., Романова І. В., Андрух Г. П., Сарвір І. М., Гавриленко М. А., Андрух П. Г., Кудінова О. І., Алієва Т. А. Принципи побудови підготовки фахівців для лікування хворих на соматичні та психічні розлади. Медична психологія. 2011. № 3. С. 65-66.

Мороз С. М. Психопатологія і патопсихологія інвалідності внаслідок соматичних захворювань (феноменологія, механізми формування,

(C) Krupelnytska Liudmyla, Burovska Iryna

DOI (article): https://doi.org/10.32626/2227-6246.2021-52.106-135 
DOI: https://doi.org/10.32626/2227-6246.2021-52

2021. випуск 52

принципи соціальної реабілітації): автореф. дис. ... д-ра мед. наук: 19.00.04. Харків, 2010. 39 с.

Оганесян С. Л., Губина С. Т., Кароян А. А. Психологические изменения личности при сахарном диабете. Новый университет. Серия: Актуальные проблель гуланитарных и общественных наук. 2015. № 10 (55). С. 43-47.

Попова Т. А. Смысложизненные ориентации и локус контроля личности как ресурсы благополучного старения. Вестник Перлского государственного гуланитарно-педагогического университета. Серия № 1 «Психологические и педагогические науки». 2019. С. 49-58.

Руденко Л. М., Гавриленко Ю. В., Осадча Т. М. Дослідження емоційних порушень у дітей молодшого шкільного віку, хворих на цукровий діабет типу I. Науковий вісник Миколаӥвського національного університету іл. В. О. Сухоллинського. Серія: Психологічні науки. 2016. № 1. С. 176-180.

Сайт Міністерства охорони здоров'я України. Всесвітній день боротьби з діабетом: що треба знати про хворобу. URL : https://moz. gov.ua/article/health/vsesvitnij-den-borotbi-z-diabetom-scho-trebaznati-pro-hvorobu.

Ткаченко О. В. Діабетична патоперсонологія: якості особистості та динаміка їх змін у хворих на цукровий діабет 2-го типу. Медична психологія. 2017. № 3. С. 17-20.

Ткаченко О. В. Особливості реагування на захворювання у хворих на цукровий діабет 2-го типу залежно від ступеня його тяжкості. Медична психологія. 2017. № 1. С. 27-30.

Штифурак В. С., Шпортун О. М. Феноменологія, практика та корекція психологічного здоров'я особистості. Вінниця : Едельвейс, 2019. 342 c.

Штрахова А. В., Арсланбекова Э. В. Мотивационный компонент внутренней картины болезни как фактор приверженности к терапии у больных соматическими заболеваниями с витальной угрозой. Вестник ЮУрГУ. 2011. № 29. С. 82-89.

García-Alandete, J., Marco, J. H., \& Pérez, S. (2017). Purpose-in-Life Test: Comparison of the Main Models in Patients with Mental Disorders. The Spanish Journal of Psychology, 20, 1-9. DOI 10.1017/ sjp.2017.28.

Hajihasani, M., \& Naderi, N. (2020). Death Anxiety in the Elderly: The Role of Spiritual Health and Perceived Social Support. Aging Psychology, 6 (4), 309-319. DOI 10.22126/jap.2020.5778.1473.

Heidarzadeh, M., \& Amohammadi, M. A. (2017). Spiritual Growth in Patients with Type II Diabetes Mellitus: A Qualitative Study. Journal (C) Krupelnytska Liudmyla, Burovska Iryna

DOI (article): https://doi.org/10.32626/2227-6246.2021-52.106-135 http://journals.uran.ua/index.php/2227-6246 
of Research Development in Nursing \& Midwifer, 14 (2), 34-44. DOI 10.29252/jgbfnm.14.2.34.

Joyce, S., Shand, F., Tighe, J., Laurent, S. J., Bryant, R. A., \& Harvey, S. B. (2018). Road to resilience: a systematic review and metaanalysis of resilience training programmes and interventions. $B M J$ Open, 8. DOI 10.1136/bmjopen-2017-017858.

Panahi, R., Ahmadi, A., Amjadian, M., Khasi, B., Noori, E., Ghajari, H., ... \& Ghaderi, N. (2019). A study on the relationship between spiritual health and quality of life in patients with type 2 diabetes mellitus. Chronic Diseases Journal, 7 (2), 73-79. DOI 10.22122/cdj.v7i2.386.

\section{References}

Vasilenko, T. D., Mangushev, F. Yu., \& Selin, A. V. (2016). Smyslovyie aspekty telesnogo opyta khronicheskogo somaticheskogo zabolevaniia [Semantic aspects of corporal experience in a chronic somatic disease]. Kurskii nauchno-prakticheskii vestnik «Chelovek i ego zdorovie» - Kursk Scientific and Practical Bulletin «Person and His Health», 2, 116-121 [in Russian].

Voloshko, N. I. (2015). Psykhosomatychni khvoroby yak rezultat vplyvu nehatyvnykh psykholohichnykh faktoriv [Psychosomatic illnesses as a result of influence of negative psychological factors]. Zbirnyk naukovykh prats "Problemy suchasnoi psykholohii» - Collection of Research Papers "Problems of Modern Psychology», 30, 126-135 [in Ukrainian].

Kachan, E. P., \& Kulak, A. I. (2015). Osobennosti vnutrennei kartiny bolezni $\mathrm{u}$ patsiientov $\mathrm{s}$ sakharnym diabetom 2-go tipa $\mathrm{v}$ zavisimosti ot dlitelnosti zabolevaniia [The features of the internal picture of the disease in patients with diabetes mellitus type 2, depending on the duration of the disease]. Zhurnal Belorusskogo gosudarstvennogo universiteta. Filosofiia. Psikhologiia - Journal of Belarusian State University. Philosophy and Psychology, 1, 108-114 [in Russian].

Kyrylova, O. O. (2017). Novyi pidkhid do vyvchennia lokusu kontroliu zdorovia $\mathrm{v}$ pidlitkiv iz tsukrovym diabetom I typu [A new approach to studying health locus of control of adolescents with type 1 diabetes]. Ukrainskyi zhurnal dytiachoi endokrynolohii - Ukrainian Journal of Pediatric Endocinology, 1, 16-20 [in Ukrainian].

Koshanskaia, A. G. (2007). Vzaimosviazi psikhologicheskikh i klinicheskikh kharakteristik $\mathrm{u}$ bolnykh sakharnym diabetom II tipa pri razlichnykh variantakh ego techeniia [The relationship of psychological and clinical characteristics in patients with type II diabetes mellitus in different variants of its course]. Candidate's thesis. Sankt-Peter-

(c) Krupelnytska Liudmyla, Burovska Iryna DOI (article): https://doi.org/10.32626/2227-6246.2021-52.106-135 
DOI: https://doi.org/10.32626/2227-6246.2021-52

2021. випуск 52

burg : V. M. Bekhterev Research Psycho-Neurological Institute of Sankt-Peterburg [in Russian].

Leontiev, D. A. (2007). Psikhologiia smysla: priroda, stroeniie $i$ dinamika smyslovoi realnosti [The psychology of meaning: the nature, structure and dynamics of meaningful reality]. Moskva : Smysl [in Russian].

Leontiev, D. A. (2000). Test smyslozhiznennykh orientatsii (SZHO) [Life-meaning orientation test (LMOT)]. Moskva : Smysl [in Russian].

Maksimenko, K. S. (2015). Lichnostno-oriientirovannaia psikhoterapiia emotsionalnykh rasstroistv pri somatogeniiakh (na materiale kliniki gastroenterologicheskikh zabolevanii) [Personality-oriented psychotherapy of emotional disorders in somatogeny (on the material of the clinic of gastroenterological diseases)]. Kiev : Izdatelskii dom «Slovo» [in Russian].

Maksymenko, K. S. (2016). Osobystisno-oriientovana psykhoterapiia emotsiinykh rozladiv pry somatoheniiakh u praktytsi suchasnoi medychnoi psykholohii [Personality-oriented psychotherapy of emotional disorders in somatogeny in the practice of modern medical psychology]. Doctor's thesis. Kharkiv : V. N. Karazin national university of Kharkiv [in Ukrainian].

Manilov, I. F. (2017). Pro kontseptualni polozhennia multymodalnoi suhestyvnoi psykhoterapii [On conceptual theoretical basics of multimodal suggestive psychotherapy]. Zbirnyk naukovykh prats «Problemy suchasnoi psykholohii» - Collection of Research Papers «Problems of Modern Psychology», 36, 197-207 [in Ukrainian].

Milman, V. E. (1990). Metod izucheniia motivatsionnoi sfery lichnosti [Method of studying the motivational sphere of personality]. Praktikum po psikhodiagnostike. Psikhodiagnostika motivatsii $i$ samoreguliatsii - Workshop on psychodiagnostics. Psychodiagnostics of motivation and self-regulation, (pp. 23-43). Moskva : Izd-vo MGU [in Russian].

Mykhailov, B. V., Romanova, I. V., Andrukh, H. P., Sarvir, I. M., Havrylenko, M. A., Andruh, P. H., ... \& Aliieva T. A. (2011). Pryntsypy pobudovy pidhotovky fakhivtsiv dlia likuvannia khvorykh na somatychni ta psykhichni rozlady [Principles of construction of training for the treatment of patients with somatic and mental disorders]. Medychna psykholohiia - Medical psychology, 3, 65-66 [in Ukrainian].

Moroz, S. M. (2010). Psykhopatolohiia i patopsykholohiia invalidnosti vnaslidok somatychnykh zakhvoriuvan (fenomenolohiia, mekhaniz-

(C) Krupelnytska Liudmyla, Burovska Iryna

DOI (article): https://doi.org/10.32626/2227-6246.2021-52.106-135 
DOI: https://doi.org/10.32626/2227-6246.2021-52 2021. ВИПУСК 52

my formuvannia, pryntsypy sotsialnoi reabilitatsii) [Psychopathology and pathopsychology of disability because of somatic diseases (phenomenology, forming mechanisms, principles of psychosocial rehabilitation)]. Extended abstract of Doctor's thesis. Kharkiv : Khark. med. acad. of postgrad. education [in Ukrainian].

Oganesian, S. L., Gubina, S. T., \& Karoyan, A. A. (2015). Psikhologicheskiie izmeneniia lichnosti pri sakharnom diabete [Psychological changes of personality in diabetes mellitus]. Novyi universitet: aktualnyie problemy gumanitarnykh i obshchestvennykh nauk - New University: Actual Problems of the Humanities and Social Sciences, 10 (55), 43-47 [in Russian].

Popova, T. A. (2019). Smyslozhiznennyie oriientatsii i lokus kontrolia lichnosti kak resursy blagopoluchnogo stareniia [Life-meaning orientations and personality control locus as resources for successful aging]. Vestnik Permskogo gosudarstvennogo gumanitarno-pedagogicheskogo universiteta. Seriia № 1 "Psikhologicheskiie i pedagogicheskiie nauki» - Bulletin of Perm State Humanitarian Pedagogical University. Series No. 1 "Psychological and Pedagogical Sciences», (pp. 49-58) [in Russian].

Rudenko, L. M., Havrylenko, Yu. V., \& Osadcha, T. M. (2016). Doslidzhennia emotsiinykh porushen $\mathrm{u}$ ditei molodshoho shkilnoho viku, khvorykh na tsukrovyi diabet typu I [Exanination of emotional disorders in junior schoolchildren with type 1 diabetes]. Naukovyi visnyk Mykolaivskoho natsionalnoho universytetu im. V. O. Sukhomlynskoho. Seriia: Psykholohichni nauky - Scientific Bulletin of V. O. Sukhomlynskyi National University of Mykolaiv. Series: Psychological Sciences, 1, 176-180 [in Ukrainian].

Sait Ministerstva okhorony zdorovia Ukrainy [Site of Ministry of Health of Ukraine]. Retrieved from https://moz.gov.ua/article/health/ vsesvitnij-den-borotbi-z-diabetom-scho-treba-znati-pro-hvorobu [in Ukrainian].

Tkachenko, O. V. (2017). Diabetychna patopersonolohiia: yakosti osobystosti ta dynamika yikh zmin u khvorykh na tsukrovyi diabet 2-ho typu [Diabetic patho-personology: personality qualities and dynamics of the changes in type 2 diabetes mellitus]. Medychna psykholohiia Medical Psychology, 3, 17-20 [in Ukrainian].

Tkachenko, O. V. (2017). Osoblyvosti reahuvannia na zakhvoriuvannia $\mathrm{u}$ khvorykh na tsukrovyi diabet 2-ho typu zalezhno vid stupenia yoho tiazhkosti [The features of response to disease in patients with type 2 diabetes depending on the disease severity]. Medychna psykholohiia - Medical Psychology, 1, 27-30 [in Ukrainian].

(C) Krupelnytska Liudmyla, Burovska Iryna DOI (article): https://doi.org/10.32626/2227-6246.2021-52.106-135 
DOI: https://doi.org/10.32626/2227-6246.2021-52

2021. виПУСК 52

Shtyfurak, V. S., \& Shportun, O. M. (2019). Fenomenolohiia, praktyka ta korektsiia psykholohichnoho zdorovia osobystosti [Phenomenology, practice and correction of psychological health of person]. Vinnytsia : Edelveis [in Ukrainian].

Shtrahova, A. V., \& Arslanbekova, E. V. (2011). Motivatsionnyi komponent vnutrennei kartiny bolezni kak faktor priverzhennosti k terapii $\mathrm{u}$ bolnykh somaticheskimi zabolevaniiami s vitalnoi ugrozoi [The motivational component of the internal picture of the disease as a factor of adherence to therapy in patients with somatic diseases with a vital threat]. Vestnik YUUrGU - SUSU Bulletin, 29, 82-89 [in Russian].

García-Alandete, J., Marco, J. H., \& Pérez, S. (2017). Purpose-in-Life Test: Comparison of the Main Models in Patients with Mental Disorders. The Spanish Journal of Psychology, 20, 1-9. DOI 10.1017/ sjp.2017.28.

Hajihasani, M., \& Naderi, N. (2020). Death Anxiety in the Elderly: The Role of Spiritual Health and Perceived Social Support. Aging Psychology, 6 (4), 309-319. DOI 10.22126/jap.2020.5778.1473.

Heidarzadeh, M., \& Amohammadi, M. A. (2017). Spiritual Growth in Patients with Type II Diabetes Mellitus: A Qualitative Study. Journal of Research Development in Nursing \& Midwifer, 14 (2), 34-44. DOI 10.29252/jgbfnm.14.2.34.

Joyce, S., Shand, F., Tighe, J., Laurent, S. J., Bryant, R. A., \& Harvey, S. B. (2018). Road to resilience: a systematic review and metaanalysis of resilience training programmes and interventions. BMJ Open, 8. DOI 10.1136/bmjopen-2017-017858.

Panahi, R., Ahmadi, A., Amjadian, M., Khasi, B., Noori, E., Ghajari, H., ... \& Ghaderi, N. (2019). A study on the relationship between spiritual health and quality of life in patients with type 2 diabetes mellitus. Chronic Diseases Journal, 7 (2), 73-79. DOI 10.22122/cdj.v7i2.386.

Крупельницька Людмила, Буровська Ірина. Мотиваційно-смислові профілі хворих на цукровий діабет

\section{АНОТАЦІЯ}

У вступі зазначено актуальність проблеми дослідження особливостей мотиваційно-смислової сфери хворих на цукровий діабет: саме ия сфера відіграє провідну роль у формуванні як «здорових», так $i$ "хворобливих» установок хворих.

(C) Krupelnytska Liudmyla, Burovska Iryna

DOI (article): https://doi.org/10.32626/2227-6246.2021-52.106-135 
Метою статmі є встановлення, аналіз та опис мотиваційно-смислових профрілів хворих на цукровий діабет.

Використано такі методи: теоретичний аналіз та узагальнення положень, що містяться у психологічній і медичній літературі за темою дослідження; психодіагностичні методи, а саме: тест «Смисложиттєві орієнтації» (Леонтьев, 2000), тест "Діагностика мотиваційної структури особистості» (Мильман, 1990). Також використано методи математичної статистики для аналізу отриманих даних.

Результати дослідження. У дослідженні взяли участь 79 осіб, які перебували на лікуванні у Київському міському ендокринологічному центрі; з них чоловіків - 31, жінок - 48, середній вік - 52,22, $\sigma-16,61$. у 25 осіб було діагностовано цукровий діабет 1-го типу, у 54 - цукровий діабет 2-го типу.

Установлено, що узагальнений мотиваційно-смисловий профріль хворих на цукровий діабет відображає середній рівень осмисленості життя, знижений рівень цілей, задовільний інтерес до життя та задоволеність самореалізацією. Низький показник локусу контролю-Я поєднується з достатнім показником локусу контролю-життя: досліджувані вірять у принципову можливість керування життям, однак не вірять у власну здатність його контролювати. Досліджуваним характерно переважання мотивів виживання в умовах хвороби, схильність до відмови від творчої самореалізації й участі у суспільному житті.

За допомогою кластерного аналізу виокремлено та проаналізовано 5 кластерів, що містять специфрічні профрілі хворих на цукровий diaбет: "типові»; "осмислені»; "суперечливі ізолячіоністи»; "заклопотані самозбереженням» $і$ «беззмістовні».

Проведений аналіз дав змогу зробити висновки щодо змісту та рівня мотиваційно-смислових параметрів хворих на чукровий діабет загалом, а також осіб, які увійшли до окремих кластерів. До перспектив подальших розвідок належать пошук зв'язків мотиваційно-смислових профрілів з особистісними чинниками, виявлення чинників, що впливають на характер організації мотиваційно-смислової структури у хворих на цукровий діабет.

Ключові слова: хворі на чукровий діабет, мотиваційно-смислові профрілі, кластерний аналіз, кластери, мотиви, смисли, смисложиттєві орієнтаuіï.

C Krupelnytska Liudmyla, Burovska Iryna DOI (article): https://doi.org/10.32626/2227-6246.2021-52.106-135 
DOI: https://doi.org/10.32626/2227-6246.2021-52

2021. випуск 52

Крупельницкая Людмила, Буровская Ирина. Мотивационно-смысловые профили больных сахарным диабетом

\section{АННОТАЦИЯ}

Во введении отмечена актуальность проблемы исследования особенностей мотивационно-смысловой среры больных сахарным диабетом: именно эта сфера играет ведущую роль в формировании как "здоровых», так и "болезненных» установок больных.

Цель статьи состоит в установлении, анализе и описании мотивационно-смысловых профилей больных сахарным диабетом.

Использованы следующие методы: теоретический анализ и обобщение положений, содержащихся в психологической и медицинской литературе по теме исследования; психодиагностические методы, а именно: тест "Смысложизненные ориентации» (Леонтьев, 2000), тест "Диагностика мотивационной структуры личности» (Мильман, 1990). Также использованы методы математической статистики для анализа полученных данных.

Результаты исследования. В исследовании приняли участие 79 лии, находившихся на лечении в Киевском городском эндокринологическом центре; из них мужчин - 31, женщин - 48, средний возраст - 52,22, $\sigma-16,61$. у 25 из них был диагностирован сахарный диабет 1-го типа, у 54 - сахарный диабет 2-го типа.

Установлено, что обобщенный мотивационно-смысловой профиль больных сахарным диабетом отражает средний уровень осмысленности жизни, сниженный уровень целей, удовлетворительные интерес к жизни и удовлетворенность самореализацией. Низкий показатель локуса контроля-Я сочетается с достаточным показателем локуса контроля-жизнь: испытуемые верят в принципиальную возможность управления жизнью, однако не верят в собственную способность ее контролировать. Испытуемым характерно преобладание мотивов выживания в условиях болезни, склонность к отказу от творческой самореализации и участия в общественной жизни.

С помощью кластерного анализа выделены и проанализированы 5 кластеров, содержащих специфические профили больных сахарным диабетом: «типичные»; "осмысленные»; "противоречивые изолячионисты»; "озабоченные самосохранением» и «неосмысленные».

Проведенный анализ позволил сделать выводы относительно содержания и уровня мотивационно-смысловых параметров больных са(c) Krupelnytska Liudmyla, Burovska Iryna

DOI (article): https://doi.org/10.32626/2227-6246.2021-52.106-135 http://journals.uran.ua/index.php/2227-6246 
DOI: https://doi.org/10.32626/2227-6246.2021-52

2021. ВИПУСК 52

харным диабетом в иелом, а также лии, вошедших в отдельные кластеры. К перспективам дальнейших исследований относятся поиск связей мотивационно-смысловых профилей с личностными фракторами, выявление факторов, влияющих на характер организации мотивационно-смысловой структуры у больных сахарным диабетом.

Ключевые слова: больные сахарным диабетом, мотивачионносмысловые профили, кластерный анализ, кластеры, мотивы, смыслы, смысложизненные ориентации.

Original manuscript received March 10, 2021 Revised manuscript accepted April 14, 2021 